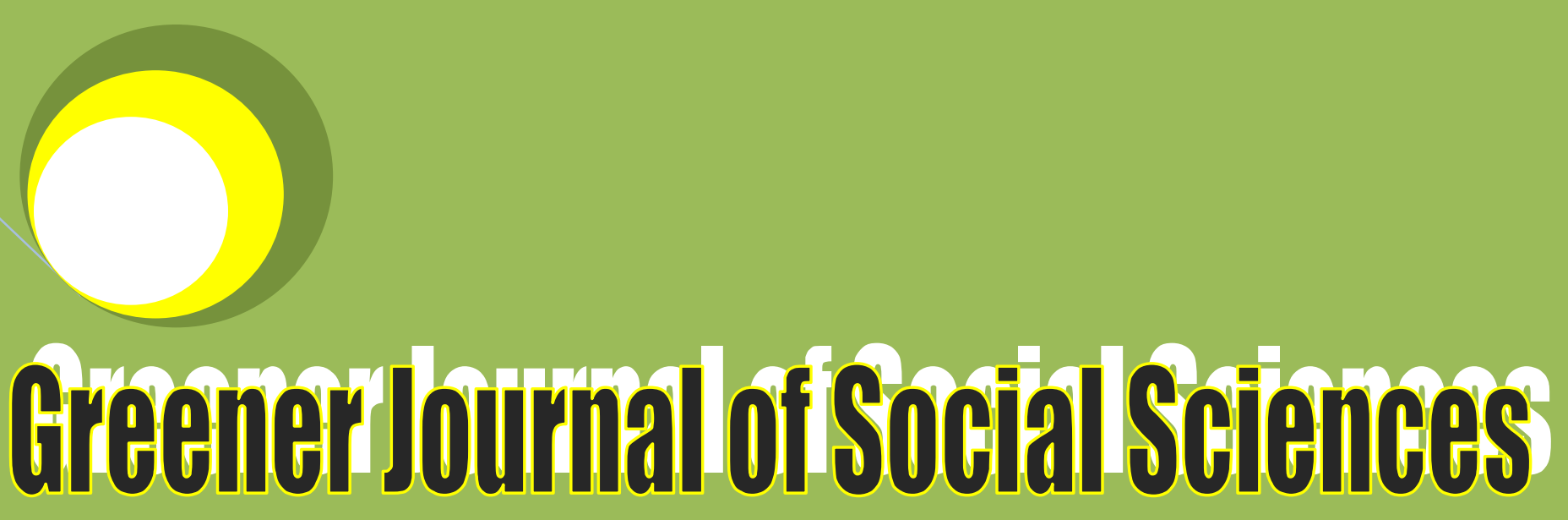

ISSN: 2276-7800 ICV: 5.99

Submitted: 19/04/2017

Accepted: 26/04/2017

Published: 10/05/2017

DOI: http://doi.org/10.15580/GJSS.2017.2.041917052

\title{
The Influence of Christianity and Modernity on Youth Sexuality in Kisii Central Sub-County, Kenya
}

By

Everlyne Chetambe Boaz K. Onyancha Joshua O. Ayiemba 


\title{
The Influence of Christianity and Modernity on Youth Sexuality in Kisii Central Sub-County, Kenya
}

\section{Everlyne Chetambe*, Boaz K. Onyancha \& Joshua O. Ayiemba}

\author{
Dept. of Philosophy, History and Religious Studies, Egerton University, Njoro, Kenya. \\ *Corresponding Author's E-mail: everlynechetambe@ gmail. com
}

\begin{abstract}
Before the advent of Christianity in Africa, the Abagusii community had systems of teaching youth responsible sexual behaviour. This prepared them for adolescent and adult experiences. However, the introduction of Christianity and modernity in Kisii Central Sub-County over a century ago has created a new culture which has interfered with these traditional systems. This study was carried out to investigate the influence of Christianity and modernity on youth sexuality in Kisii Central Sub-County. Qualitative method of research was employed. Information was gathered using questionnaires and interviews. Selected youth, youth leaders, pastors, priests and catechists from selected SDA and Catholic Churches formed the sample of 108 respondents. The study found out that Christianity and modernity have negatively influenced youth sexuality education in the area under study. They have weakened the moral fibre because the community hardly provides informal education for socialization of its youth as it did before. Besides, though churches organised youth programmes to teach youth on sexuality issues, youth rated them as inadequate. This causes uncertainty on sexuality matters and inclines youth to unreliable sources (peers, mass media and social networks).
\end{abstract}

Key words: Influence, Christianity, Modernity, Youth sexuality, Church, Morality.

\section{INTRODUCTION}

Social changes are products of political and industrial revolutions and urbanization since the $18^{\text {th }}$ Century. The inflow of technology, new trends and modern products from developed nations is swift. Inability to address these changes affects youth's choices and requires parallel capacity in guidance and counselling.

The communal African Traditional Society (ATS) system of child-rearing was achieved through up-bringing and "initiation and puberty rites" (Mbiti, 1989:118). Parents and responsible adults educated children on general life (lbid: 132). Among the Abagusii, boys moved to huts (chisaiga) meant for young unmarried men or special compounds away from homes (gesarate) at the age of ten. Here, male clan elders and young men guarded, tended and lived with livestock. Boys were educated on animal husbandry, acquisition of wealth (for bride price), and responsible leadership of future families (Ochieng', 1974). The Kisii initiates to-be spent a month in the gesarate learning "...endurance, temper, bravery...and intellect" (Bosire and Machogu, 2013:1422). The girls joined others at the grandmother's house at age eight to await initiation and eventually marriage (lbid). They were taught cookery, responsible behaviour towards men, how to care for children and husbands, and other domestic issues. Their teachers were mothers, aunties, grandmothers and older women who spend most of their time with them (Mbiti, 1989).

Later, youth were introduced to adult-life through initiation/puberty rites. They were educated on sexuality and sex, marital life, procreation and overall family responsibilities (Sharkey and Welch, 1979; Mbiti, 1989). In ATS education, mentorship was employed; the young and inexperienced learnt from adults who had superior knowledge, experience and insight (Mbiti, 1977). Regardless of the absence of a written syllabus, the system had definite aims (Sharkey and Welch, 1979; Mbiti, 1990). This prepared youth physically, mentally, morally and emotionally for adolescent and adulthood experiences. However, currently, many parents assume that it is the responsibility of schools to "develop the character, moral values and religious understanding" of youth alongside teaching them "all knowledge and skills" for life (Sharkey and Welch, 1979: 67).

Nevertheless, the family remains the only institution with the greatest impact on young people's basic values and choices. Parents, being the closest people to their children, have the strongest influence on their character formation because they spend the early years together. 
Although missionaries brought Western education and a new civilization, it perpetuated a new form of morality that was initially Christian-oriented but turned out to be materialistic, and is cultivated by mass media (Bennaars, 1993). Christianity and modernity encourage free interaction of youth of opposite sexes in Church, schools, colleges and other forums. Today's society seems to provide limited guidance and counselling to youth. Christianity, Western education and modernity might be blamed for this paradigm shift. Kinship links have grown weak and relativism thrives (Maynard, 1970), escalating broken families and loose morals. These are pointers to the possible challenges that Christianity and modernity have brought to the ATS.

\section{Purpose}

The purpose of this paper is to share with the readers the findings of a recent investigation on the influence of Christianity and modernity on youth sexuality in SDA and Catholic churches in Kisii Central Sub-County, Kisii County. These churches, being dominant in the area, have youth sexuality programmes. However, Catholic Church programmes are not as detailed compared to the SDA Church whose programmes are structured to cater for various ages and needs. Despite provision of sexuality education by churches, young people do not appreciate these teachings as depicted from the findings. Besides, youth are inclined to unreliable sources of information on sexuality issues including peers, social networks and mass media rather than from responsible adults. The findings also indicate that parents have lost their moral obligation as primary sources of sexuality education. Consequently, the youth are predisposed to pre-marital sex and its attendant challenges.

\section{Justification}

The influence of Christianity and modernity on youth sexuality based in the sub-county is not clear. This paper intends to show that youth are affected by pre-marital sex and its related challenges including pre-marital pregnancy, abortion and STIs regardless of Church teachings on sexuality and sex, pre-marital sex, pregnancy out of wedlock, abortion, STIs and mentorship. The research findings site a high rate of children born out of wedlock due to early sexual experimentation. Besides, stakeholders should appreciate the challenges youth encounter in order to work out intervention measures, including sharpening skills in guidance and counselling amongst themselves.

\section{THEORETICAL AND CONCEPTUAL FRAMEWORKS}

\section{Theoretical Framework}

This study was based on dysfunctionalism theory proposed by Merton (1968) which postulates that not all structures contribute positively to society. A social structure could produce negative results for another while at the same time it maintains other parts of the social system. Merton introduced human functions and divided them into manifest (intentional and obvious) and latent (unintentional and not obvious) functions. He related them to anticipated consequences (functional) that make positive contributions and unanticipated consequences (not necessarily obvious and dysfunctional) to society because they make negative contributions. This paper concludes that although Christianity and modernity exist in Kisii Central Sub-County, they have negative influences on youth sexuality, hence early sexual debut.

\section{METHODOLOGY}

The findings of this paper are results of a field study involving one hundred and eight respondents from SDA and Catholic churches sampled using purposive, snowball and stratified random sampling methods. Their church membership, age, sex, academic achievements and leadership roles were considered. Data was collected using questionnaires, observations and interviews schedules. Document analysis from Kisii Teaching and Referral Hospital was conducted to corroborate the data collected. The major limitation was lack of previous studies on the influence of Christianity and modernity on youth sexuality. However, materials related to the topic were used to validate the findings. 


\section{LITERATURE REVIEW}

Havighurst and Taba (1949) argue that most youth who rebel are eager to embrace moral values. Their rebellion and misconduct are normally based on causes rather than rejection of moral values. Most people who reject Christian traditions are children of religious parents, who displace their rebellion against their family on religion (Adorno et al., 1950). Christian parents should understand emancipation to develop it wisely. These studies are relevant to this paper although they do not assess the impact of Christianity and modernity on youth sexuality, which the current study addresses.

Ausubel (1954) analyses the challenges of adolescents as they develop; a process of synthesis called "inherent sacredness of moral standards". He asserts that it starts to break down when parents begin to lose value. This occurs when children become aware of other authorities, experience moral alternatives, and a variety of truths. As youth join older peers with clearly differentiated roles and participate in formulation of rules, a functional rather than "sacred" concept of moral law emerges. This explains the cause of pre-marital sex among youth in Kisii Central Sub-County. However, youth's perception of sexuality in relation to Christianity and modernity, which the current paper tackles, has not been included.

Stable, mature character is related to parental trust and faith in children (Peck and Havighurst, 1960). They affirm that children's readiness to confide in parents, children's approval by parents, parents' approval of children's peer activities and friendly inter-parental relationships have a role in children's character formation. Therefore, sound character is related to positive family traits. An autocratic home environment breeds rigid conformity, meaning mentorship is majorly parental responsibility. Other social institutions are supplementary. This work provided useful information to this paper although it does not discuss the impact of Christianity and modernity on youth sexuality.

Patterns and growth in personality are explored by Allport (1961) who confirms that youth may not necessarily be against parents' values, but they want their own. Therefore, youth leaders should help them in their identity crises, overcome identity diffusion, affirm them during their best moments and serve as adult guarantors to their children (Yates, 1969). Yates challenges adults to concentrate on improving themselves rather than criticising youth. Rogers (1969) notes that youth are greatly disturbed by what adults portray including hypocrisy, injustices, sex and drugs. Adults need to say with Paul: 'Follow me as I follow Christ' (I Corinthians 11:1). Youth are not eager for perfection but sincerity, fairness and openness from adults. This perspective is general on youth sexuality without considering Christianity and modernity, which the current paper covers.

Maynard (1970) emphasises the role of education in producing responsible people and notes that intelligence is inborn while character is mainly acquired and can be remoulded. The closest people to youth ought to influence their character as they have more interactions with them in formative years. However, the findings of this paper indicate that parents have absconded their responsibility.

Combs, Arila, and Purkey (1971) acknowledge that pre-marital pregnancy gets youth off-guard. Their behaviour seems a product of sound judgement, but regrettable when pregnancy occurs. When youth have sex, they never think of pregnancy. The paper's focus is, however, on helping relationships rather than youth sexuality.

Effectiveness in youth ministry depends more on "who you are as a leader" than on any other factor (Richards, 1972). Richards asserts that due to youth alienation from churches, ministry among them must dependent on understanding how they experience, feel and view life. The paper proposes that values are embodied in culture and are a product of interpersonal relationships. Therefore, behaviour is the true indicator of values. Consequently, Christian ministry should guide youth in learning how to evaluate values through their choices and how they express feelings. The emphasis is that "youth ministry must be redesigned" on "culture communication, life to life", not "Western classroom education". Essentially, this paper established that youth ministry should facilitate relationships and interactions with youth should be informal and interactive.

Rogers (1972) suggests that adults tend towards maintaining status quo and resist change. Youth, the study argues, often view handed-down values as inappropriate but seek cues from adults and adjust them to prevailing conditions. This underscores mentorship because the success of youth emancipation depends on parents.

Schiamberg (1973) argues that youth seeking identity also struggle to gain independence "from...important others as parents, teachers...." As youth grow intellectually and struggle to be independent, they tend to challenge many previously accepted guidelines, mainly those emphasized by parents and churches. This suggests that mentorship from "significant others" is the best spirited-fight to overcome peer influence. This analysis expounds adolescent alienation, excluding youth sexuality in a rapidly changing society.

The Abagusii youth were "informally instructed" concerning their traditions (Ochieng', 1974), after evening meals, around fires in the huts of elders as folklore, songs and dances. Any behaviour that did not reflect God's intrinsic qualities was treated as rebellion, punishable by God unless the offender took personal remedial action and for the sake of the community. Such behaviour included adultery, incest and other related offences. The community upheld "strong and strictly observed taboos" (p.190) that upheld social standards. However, this paper established 
that this hardly occurs nowadays as peers, mass media and social networks have taken over hence pre-marital sex among youth. The influence of Christianity and modernity on youth sexuality is not part of the investigation.

Dudley (1978) proposes that the challenges youth go through can be seen through the eyes of youth rather than adults. The findings of this paper point to wrong climates of relationships between youth and parents, and the absence of guidance as key causes to youth not seeking counsel from older and more experienced persons. This limits guidance when needed. Dudley expounds on what makes youth to reject religion and possible solutions but excludes the influence of Christianity and modernity on youth sexuality.

Bahemuka (1982) ascertains that "...missionaries...preached against everything African" (p.30). African culture was termed uncivilized and harmful to development. She supports initiation rites in socialization of youth and virginity that was treasured by most African communities, unlike modern times dominated by early sexual experimentation as noted in this paper's findings. However, the attitude of youth to sexuality in relation to Christianity and modernity is not covered in the work.

AIDS prevention has been studied and successful approaches have been applied in developed countries. Suggestions that the Church can help youth through championing behavioural change through messages of abstinence and fidelity to the unmarried and married respectively to lower the HIV risk, and indirectly delay the age at first sex have been advanced (Green, 2003; Parsitau 2009). The attitude of youth to sexuality in relation to Christianity and modernity is not covered in the work.

Many people perceive sex as a 'personal bedroom issue...' (Tabifor and Mulyanga, 2003). Africans believe in public, "the less said about it the better" (Maranga et al., 2008). This prejudice contributes to ignorance among youth, prompting them to mass media and social networks. These studies affirm that today's society exposes youth to so much sex literature. This has influenced many to pre-marital sex due to lack of guidance. Besides, Maranga et al., ascertain that the $21^{\text {st }}$ Century is witnessing early sexual debut among teenagers below 15 years because information on sex is available to them from unreliable and inaccurate sources. They propose that friendship for both sexes is healthy for youth. Nevertheless, this paper established that the influence of unrestrained passion has made these interactions degenerate into sexual perversion. KESSP (2009) opines that youth need preparation to develop and apply life skills and critical judgment to enable them socialize easily and confidently. The evaluations are relevant and validate the findings of this paper although they do not mention the attitude of youth to sexuality in view of Christianity and modernity.

Trinitapoli (2006) avers that youth need time together as friends without sexual involvement and propose that proper association of both sexes benefits youth although majority of today's youth view these relationships as sexual. Trinitapoli supposes that delaying of first sex, even shortly, can have valuable effects on HIV infection rates, because it lowers the time spent in the most dangerous period of infection among youth. The study argues that churches can reach many people, including youth who are not attending school. However, the assessment does not encompass the attitude of youth to sexuality in relation to Christianity and modernity.

Were (2007) mentions proxies that can assist youth to access sex education including church forums that teach adolescents on sex and family life as avenues that can minimise teenage pregnancy. The work lists peer pressure, inappropriate leisure activities, absence of guidance and counselling from parents, inaccessibility to formal education and endemic poverty as factors that perpetuate teenage pregnancy. The evaluation is relevant to the findings of this paper although it does not mention the influence of Christianity and modernity on youth sexuality.

The National Co-ordinating Agency for Population and Development (2010) evaluated protection of the reproductive health of youth as an investment into the future of Kenya. It contends that teenagers constitute a large part of the Kenyan population (Of the 39 million people, one in every four Kenyans aged between 10-19 years is an adolescent), necessitating government promotion of healthy behaviour and prevention of diseases among them. The study affirms that some sexually active youth (15-19 years) had their first sexual encounter at age 12 . Moreover, $50 \%$ of all Kenyan women get married by age of 20 and by this age, they are already mothers. Many of these youngsters engage in risky sexual behaviours including early sexual activity, multiple sexual partners, sexual encounters with men older than them and temporary sexual relationships. These practices have grave consequences including early marriages, still practised in North Eastern, Nyanza and Coast provinces. NCAPD focus on adolescents due to their vulnerability to illnesses and deaths that result from early pregnancy, abortion and STIs. This work lacks depth on sexuality despite having key facts that are vital to this paper.

Several scholars have studied the SDA Church in Kisii. Onyancha (1989) investigated African spiritual response to Western Christianity with reference to Abagusii and the SDA Church in Ogembo Division. The role of the Church in rural development in the SDA Church in South Nyanza was studied by Ayiemba (1992) while the place and role of women in the SDA Church in Kenya was analysed by Okemwa (1993). Nyaundi (1993) has concentrated on religion and social change in the SDA Church in Kenya. However, the influence of Christianity and modernity on youth sexuality in Kisii has not been covered by the scholars in their studies. This is a clear evidence of scanty information about the SDA and Catholic churches on youth sexuality. The current paper intends to fill this knowledge gap by highlighting sexual explosion in the area. 


\section{FINDINGS}

The findings were discussed based on the purpose and objectives of this paper. The first objective was to investigate the effects of Christianity and modernity on youth sexuality in Kisii Central Sub-County and the second objective was to examine the attitude of youth to sexuality in view of Christianity and modernity. The paper confirms that churches run programmes to empower youth on sexuality. The teachings include sexuality and sex, pre-marital sex, pregnancy out of wedlock, STIs, abortion and mentorship.

It also established that although youth are often taught sexuality education at church, they are not contended with coverage of certain aspects including sexuality and sex, pregnancy out of wedlock and abortion. However, Church leaders felt that the sexuality education offered was sufficient except on abortion. The interviews highlighted that although youth attend church and youth meetings, many do so as submission to parents. They display it in errant sexual tendencies.

Besides, the paper avers that the major sources of information for youth on sexuality issues are peers, mass media and social networks, respectively. Church leaders indicated that youth hardly rely on them/church members and teachers for information on sexuality matters; a sign that something needs to be done to remedy the situation.

It was established that sexual deviance among youth also originates from some parents/Church leaders who are not role models to their own children away from Church. Some Church leaders had reportedly taken advantage of female youth during counselling and youth camps to an extent of sexual harassment. It was explained that despite such cases being few, the impact is tremendous (Pastor Atemba, OI).

Church leaders ascertained that some youth confided in them about their parents' ungodly habits including sexual immorality, hypocrisy and lies. The following are some phrases used by youth to describe such adults: "pretenders, hypocrites, double-sided, not honest, disappointing, unreliable, has double standards". The interviews indicated that senior youth too influence junior youth negatively in social relationships. This is the ripple effect of poor role modelling among Christian adults.

The paper affirmed that the Abagusii culture forbids parents from discussing sexual matters with their children (Rev. Obanyi, OI). Consequently, some parents have challenges educating their children on sexuality. This has caused ignorance among youth, prompting them to unreliable sources (peers, mass media and social networks) as depicted by earlier findings. Reverend Obanyi (OI) further said, "This forced me to put in personal effort to encourage youth programmes in Catholic churches under my jurisdiction in Kisii region because I realised that youth were left on their own."

The paper also established that most youth long for relationships with parents/guardians (Pastor Maangi). Several homes have absentee parents for varied reasons including employment (Mary, OI). This made some parents to support sexuality education at Church. Others were partial while a few opposed it ignorantly (Pastor Makori, OI).

\section{CONCLUSIONS}

The findings of this paper were discussed based on the purpose and objectives. The first objective was to investigate the effects of Christianity and modernity on youth sexuality in Kisii Central Sub-County and the second objective was to examine the attitude of youth to sexuality in view of Christianity and modernity. The findings show that although SDA and Catholic churches often teach youth sexuality, the impact is minimal because the youth feel the efficacy of the programme is insufficient. Therefore, youth lack confidence in its quality. This explains why some youth attend church only as a way to pledge allegiance to parents/guardians. However, gaps are left in their adventurous minds.

Church leaders disagree that the sexuality education offered at Church is insufficient to meet youth's needs except on abortion. This difference is an indicator of the generation gap that exists between adults and youth. In developing countries like Kenya, the gap is bound to widen. Adult realistic perceptions seem to contrast with youthful idealism as they turn adventurously to innovation and experimentation hence conflicting norms (Dudley, 1978).

Most youth were influenced by peers, mass media and social networks respectively to errant sexual tendencies. Peer influence is depicted as a major challenge to youth sexuality despite their Christian orientation. Peers are preferred because they are more available and understanding. Mass media exposes them to further influence from additional inaccurate sources including pornographic literature and social networks. Technological advancements like mobile phones, computers and the internet enhance communication among youth. Consequently, modernity promotes peer influence thus perpetuating pre-marital sex and its attendant challenges. The findings of this paper suggest that this is propagated by lack of communication between youth and their parents/guardians (Pastor Maangi, OI), making youth vulnerable on critical decisions related to sexuality.

Since acceptance by social groups is a vital human need (Maynard, 1970), peers have a bearing on each other's day-to-day choices. They counter-balance and compensate for family imperfections, especially lack of love, appreciation, encouragement and mentorship. They "provide recognition, advice..." because they "share common 
ideas, values and behaviour" (Thompson, 2012). However, their challenge is balancing between the need to belong and being oneself amidst peer pressure and modernity. The foregone scenario is evidence that parents have lost their moral obligation as primary sources of information on sexuality for youth.

Although there were role models in SDA and Catholic churches, it was realised that youth have challenges with mentors. The double standards portrayed by some adults as noted earlier seem to be a major cause. Some youth who had challenges finding role models at Church may have been disappointed by adults that they admired. They lost confidence in adults and filled the vacuum with peers, mass media and social networks. This contributes to confusion hence the disparity they display between the theory and practice of sexual purity as taught to them at Church. Therefore, more positive influence by adults will replicate among youth because character is mainly acquired and can be remoulded (Maynard, 1970). In rural areas and low income urban areas, peer influence is perpetuated by lack of resources and the required training to facilitate sex education in Kenyan schools (KHRC and RHRA, 2010).

Lack of parental input indicates that traditional methods of socialization of youth have been interfered with by Christianity and modernity. Instead, individualism and relativism thrive in the modern society that emphasises freedom with little value for individual and social morals. This explains why there is variance between the teachings youth receive on sexuality and the prevalence of sexuality related challenges among them.

\section{RECOMMENDATIONS}

For youth sexuality programmes offered by the Church to assist in reducing pre-marital sex and its related challenges, this paper recommends the following based on findings:

1. The Church should establish feedback mechanisms to assess the influence of youth programmes on recipients. It can be done by embracing guided consultative leadership to make the education rich and fulfilling. Youth may also be included in formulation of sexuality curriculum to ensure it meets their needs.

2. More time and teachings on sexuality and sex, pregnancy out of wedlock and abortion are required to improve youth's perceptions on Church sexuality education.

3. The Church should assist youth to manage peer influence because other unconventional sources like social networks and pornographic literature thrive on it.

4. Youth and family life programmes at church ought to include enlightenment on the benefits and challenges of modern technology to adherents.

5. The Church can consider family life programmes and policies that enlighten parents on the value of parental involvement in enhancing youth sexuality education.

6. To assist youth to change their attitude towards sexual morality, adults should consistently live practical Christianity as mentors.

7. Youth ministry should be restructured to facilitate relationships including informal and interactive sessions, considering youth's needs to boost their confidence in adults.

8. Parents should reclaim their moral position as primary sources of sexuality education by strengthening family relationships to facilitate appropriate socialization of youth within the family.

\section{REFERENCES}

Adorno, T. W., Frenkel-Brunswick E., Levinson, D.J., and Sanford R. N. (1950), The Authoritarian Personality. New York: Harper and Brothers.

Allport, G. W. (1961). Pattern and Growth in Personality. New York: Holt, Rinehart and Winston.

Ausubel, D. P. (1954). Theory and Problems of Adolescent Development. New York: Grune and Straton.

Bahemuka, J. M. (1982). Our Religious Heritage. Edinburgh: Thomas Nelson and sons limited.

Bennaars G. (1993). Ethics, Education and Development: An Introductory Text for Students in African Colleges and Universities. Nairobi: East African Publishers.

Bosire, K. M. and Machogu, G.K. (2013). Authoritative Ekegusii-English Dictionary. (First Edition). Ekegusii Encyclopedia Project.

Combs, A., Arila, D. and Purkey, W. (1971). Helping Relationships: Basic Concepts for the Helping Profession. Boston: Allyan and Bacon.

Dudley, R. (1978). Why Teenagers reject Religion and what to do about it. Washington D.C.: Review and Herald Publishing Association.

Green, E. C. (2003), Rethinking AIDS Prevention: Language from Successes in Developed Countries, Westport, CT: Praeger Publishers. 
Havighurst, R. J. and Taba. (1949). .Adolescent Character and Personality. New York: John Wiley and sons.

Kenya Education Sector Support Programme (KESSP). (June, 2009). HIV and AIDS Prevention and Life Skills Training Manual. Director of Policy and Planning, Ministry of Education.

Kenya Human Rights Commission. (2010). Teenage Pregnancy and Unsafe Abortion: The Case of Korogocho Slums.

Maranga R. O., Muya, S. M. and Ogila, K. O. (2008). .Fundamentals of HIV/AIDS Education. Nairobi: Jomo Kenyatta University of Agriculture and Technology.

Maynard, N. J. (1970). Child Study: Some practical Techniques for the Teacher. (2nd Edition). Hong Kong: Oxford University Press.

Mbiti, J. S. (1977). Love and Marriage in Africa. (Second Edition). Nairobi: Longhorn.

Educational publishers.

..(1990). Introduction to African Religion. (Second Revised Edition). Nairobi: East African Educational Publishers.

Merton, R., (1968). Social Theory and Social Structure. New York: Free Press.

National Coordinating Agency for Population and Development (NCAPD) (2010) Policy Brief No.11-April 2010, Protecting the Reproductive Health of Young People-An Investment in Kenya's Future. Nairobi.

Ochieng', W. R., (1974). A Pre-Colonial History of the Gusii of Western Kenya C. A. D. 1500-1914. Nairobi: East African Literature Bureau.

Peck, R. F. and Havighurst, R. J. (1960). The Psychology of Character Development. New York: John Willey and Sons.

Richards, O. L. (1972). Youth Ministry: It's Renewal in the Local Church. Grand Rapids, Michigan: Zondervan Publishing House.

Rogers, D. (1972). The Psychology of Adolescence. (Second Edition). New York: Appleton- Century-Crofts.

Rogers, W. R. (1969). The Alienated Student. Nashville: Board of Education, the United Methodist Church.

Schiamberg, L. B. (1973). Adolescent Alienation. Columbus, Ohio: Charles E. Merill.

Sharkey, B. and Welch, F. G. (1979). Modern Christian Living. Nairobi: Oxford University Press.

Tabifor, H. and Mulyanga, S. (2003). How to Teach Children Sexuality: A Handbook for Parents and Teachers. Nairobi: Alpha and Omega Publishers.

Thompson, R. A. (2012). Professional School Counselling: Best Practices for Working in Schools (3 ${ }^{\text {rd }}$ edition). New York: Routledge.

Yates, J. E., (January, 1969), "Erikson's study of the Identity Crisis in Adolescence and its Implications for Religious Education", Dissertation Abstracts.

\section{Periodicals, Journals and Papers}

Parsitau, D. S. (2009) 'Keep Holy Distance and Abstain Till He Comes: Interrogating a Pentecostal Church's Engagements with HIV/AIDS and the Youth in Kenya, The Journal of Modern African Studies, 56 (1), 47, 45-64. Cambridge University Press.

Trinitapoli, J. (2006). "Religious Responses to AIDS in Sub-Saharan Africa: An examination of Religious Congregations in Rural Malawi." Review of Religious Research, 47, 253-270.

\section{Dissertations and Theses}

Ayiemba, J. O. (1992). "The Role of the Church in Rural Development: A case study of the SDA Church in South Nyanza District", M.A. Thesis, University of Nairobi.

Okemwa, P. F. (1993). "The Place and Role of women in the SDA Church in Kenya (1911-1990)", M.A., Kenyatta University, Kenya.

Onyancha, B. K. (1989). "African Spiritual response to Western Christianity with particular reference to Abagusii and the Seventh-Day Adventist Church in Ogembo Division, Kisii District, Kenya", M.A. Thesis, University of Nairobi.

\section{Internet Sources}

Were, M. (2007). "Determinants of teenage pregnancies: The case of Busia District in Kenya" Economics and Human Biology 5 (2007) 322-339. Retrieved from http://www.elsevier.com/locate/ehb on 23rd September, 2012.

Cite this Article: Chetambe E, Onyancha BK \& Ayiemba JO (2017). The Influence of Christianity and Modernity on Youth Sexuality in Kisii Central Sub-County, Kenya. Greener Journal of Social Sciences, 7(2): 015-021, http://doi.org/10.15580/GJSS.2017.2.041917052 